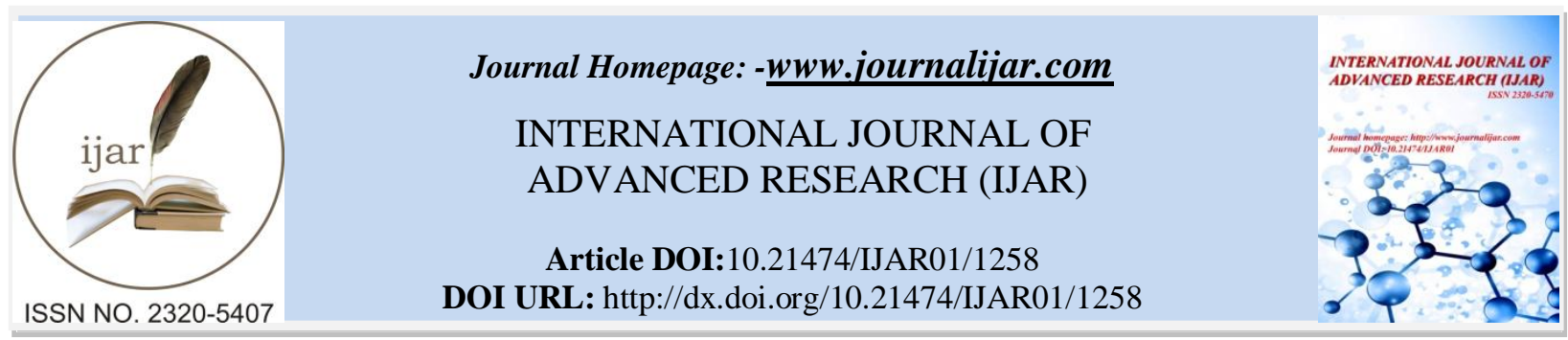

RESEARCH ARTICLE

\title{
STUDIES ON THE EFFECT OF MSG AND NATURAL GLUTAMATE ON XANTHINE OXIDASE ACTIVITY.
}

Sivapriya Balagopal, Devkar Kapil S, Diya Roy and Ribin George. Department of Research, M. E. Meeran Innovation Centre, Eastern Condiments Pvt Ltd, Cochin-682024, India.

\section{Manuscript Info}

Manuscript History

Received: 16 June 2016

Final Accepted: 19 July 2016

Published: August 2016

Key words:-

Monosodium glutamate; enzymatic assay; xanthine oxidase; UV-Vis spectrophotometer, natural glutamate.

\section{Abstract}

Monosodium glutamate is an artificial flavour enhancer that is found majorly in Chinese, Japanese cuisines and also in fast foods. Unlike natural glutamate that is mostly present in the bound form, the artificially synthesized glutamate is free which makes it a strong free radical generator leading to oxidative stress in our body. In this work, the enzymatic assay of xanthine oxidase using UV-Vis spectrophotometer at $295 \mathrm{~nm}$ was carried out to observe if there are any changes in its activity in the presence of natural and artificial glutamate, thereby analysing if there is a clear difference between artificial and natural glutamate.

Copy Right, IJAR, 2016,. All rights reserved.

\section{Introduction:-}

Although MSG has been widely used in the last few decades, researchers are still trying to make a breakthrough regarding its safe consumption. Experts of different fieldssuch as Food Science, Toxicology, Allergy etc. are applying Modern Scientific Techniques to review the existing information on glutamate.

Monosodium glutamate was first isolated by researchers from seaweed in the $1900 \mathrm{~s}^{[12,15]}$.It is the sodium salt of Lglutamic acid which is produced through a natural fermentation process or acid hydrolysis of molasses. MSG is basically composed of $78 \%$ of glutamic acid, $22 \%$ of sodium and water ${ }^{[20]}$. It was established that it generated the fifth basic taste 'umami' when added to food products.

Widespread research after emergence of Chinese restaurant syndrome revealed monosodium glutamate to have toxic effects when consumed in high doses ${ }^{[13]}$. One such study demonstrated that providing a certain dosage of MSG, increased the blood glutamate and glutamine level and amplified the lipid-peroxidation of hepatic tissues ${ }^{[6]}$.Similar studies revealed MSG to cause a wide range of adverse effects on test animals, such as stunted growth, renal damage, hepatic toxicity, male infertility, brain damage and endocrine disorders ${ }^{[4]}$.

The liver plays a crucial role in prevention of oxidative stress. A range of antioxidants and hepatic enzymes glutathione peroxidase, superoxide dismutase and catalase which have free radical scavenging abilities assist the liver cells to maintain a reduced environment under normal conditions, shielding the cell membranes and organelles from harmful effects of free radicals ${ }^{[2,23]}$. Consumption of MSG is known to alter the favourable liver environment and adversely affect its functioning, ultimately causing oxidative stress ${ }^{[25]}$.

Corresponding Author:-Devkar Kapil S

Address: -Department of Research, M. E. Meeran Innovation Centre, Eastern Condiments Pvt Ltd, Cochin-682024, India. 
Natural Glutamate exists as Glutamic acid or its ionic form and is a non-essential amino acid commonly found in high protein foods. Several proteins, polypeptides and tissues in our body are composed of glutamic acid and it also plays a vital role in metabolism ${ }^{[9,10,15]}$.

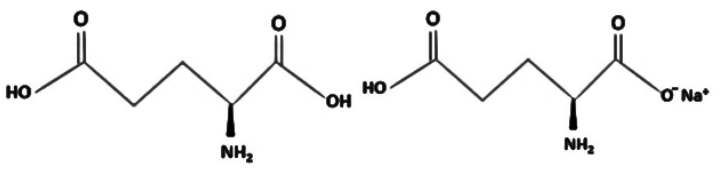

$$
\text { L-glutamic acid Monosodium glutamate }
$$

Fig 1:- Chemical structure of Natural glutamate (L- glutamic acid) and monosodium glutamate

Plant and animal tissues contain glutamate both in "free" and "bound" forms. Glutamate shows flavour enhancing properties when not bound to other amino acids in proteins. Similar flavour enhancing potential is observed in MSG

${ }^{[29]}$. Free glutamate content of some common foods are given in the Table. 1.

Table 1:-List of Free Glutamate containing foods.

\begin{tabular}{|c|c|}
\hline Food Products & Free Glutamate (mg/100g) \\
\hline Cow's Milk & 2 \\
\hline Eggs & 23 \\
\hline Chicken & 44 \\
\hline Potatoes & 102 \\
\hline Corn & 130 \\
\hline Tomatoes & 140 \\
\hline Broccoli & 176 \\
\hline Mushroom & 180 \\
\hline Soy sauce & 1090 \\
\hline *Source: The Glutamate Association, 2016 & \\
\hline
\end{tabular}

Extensive research has been conducted to yield inconclusive and contradictory result as to whether MSG is safe for our consumption. Taking into account these conflicting outcomes it becomes important to identify the difference between Natural and Artificial glutamate.

Several techniques like spectrophotometric, liquid chromatographic, amperometric and enzymatic have been employed for detection and quantification of MSG in food products ${ }^{[1,3,16,24]}$. No similar studies have been cited for natural glutamate.

The aim of the present study was to develop and validate a scientific method to distinguish the glutamate present in natural sources from artificial sources like MSG. Administration of MSG enhances the activity of free radical initiating enzyme, xanthine oxidase present in liver. The study attempts to differentiate the natural glutamate from its artificial form on the basis of their effect on xanthine oxidase activity.

\section{Materials and Methods:-}

Materials:-

Potassium phosphate buffer, xanthine, xanthine oxidase from bovine milk and L-Glutamic acid monosodium salt hydrate were purchased from Sigma Aldrich. Natural sources of glutamate like tomato and mushrooms were selected for the study due to their easy availability and similar glutamate content. They were purchased from the local super markets. UV-Vis Spectrophotometer (Shimadzu UV1800) was used for the enzymatic assay.

\section{Enzymatic assay of xanthine oxidase:-}

The activity of an enzyme is generally determined by calculating the amount of substrate that was consumed or the amount of product formed ${ }^{[19]}$.

Principle:-

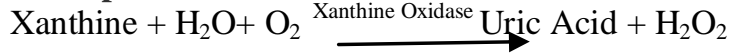


1 unit of enzyme will convert $1.0 \mu$ mole of Xanthine to Uric Acid per minute at $\mathrm{pH} 7.5$ at $25^{\circ} \mathrm{C}$. The activity of xanthine oxidase can be calculated bymeasuring the rate of depletion of xanthine or hypoxanthine or the rate of formation of uric acid ${ }^{[5,26]}$. Uric acid has a molar absorptivity coefficient of $1.1 \times 10^{4} / \mathrm{mol} / 1 / \mathrm{cm}$ at a wavelength of $295 \mathrm{~nm}^{[11]}$. The most commonly used technique for enzymatic assay of xanthine oxidase is spectrophotometric method $^{[18]}$.

\section{Conditions:-}

Temperature: $25^{\circ} \mathrm{C}, \mathrm{pH}=7.5, \mathrm{~A}_{295 \mathrm{~nm}}$, Light Path $=1 \mathrm{~cm}$.

\section{Method:-}

Continuous spectrophotometric rate determination

\section{Reagents:-}

a. $\quad 50 \mathrm{mM}$ Potassium Phosphate Buffer, $\mathrm{pH} 7.5$ at $25^{\circ} \mathrm{C}(200 \mathrm{ml}$ solution was prepared in deionised water using potassium phosphate, Monobasic, anhydrous, Sigma Prod. No. P-5379. The pH was adjusted to 7.5 at $25^{\circ} \mathrm{C}$ with $1 \mathrm{M} \mathrm{KOH})$.

b. $\quad 0.15 \mathrm{mM}$ Xanthine solution (100 $\mathrm{ml}$ of solution was freshly prepared by initially dissolving Xanthine, Sigma Prod. No. X-0626, in minimal Vol of $\mathrm{NaOH}$. Approximately $90 \mathrm{ml}$ of deionised water was added to it. The $\mathrm{pH}$ was adjusted to 7.5 at $25^{\circ} \mathrm{C}$ with either $1 \mathrm{M} \mathrm{NaOH}$ or $1 \mathrm{M} \mathrm{HCl}$. Made up the volume upto100 $\mathrm{ml}$ with deionized water.

c. Xanthine Oxidase Enzyme Solution(A solution containing 0.1 to 0.2 Unit/ml of Xanthine Oxidase in cold Potassium Phosphate Buffer was prepared immediately before use).

d. 30 grams of tomato, button mushroom and L-Glutamic acid monosodium salt hydrate were taken separately in beakers having $100 \mathrm{ml}$ water and allowed to stand for 2 hours. After which the solutions are filtered and $1 \%$ solutions of the clear filtrates are prepared using deionized water.

\section{Procedure:-}

The reagents and sample solutions freshly prepared were transferred by a pipette into suitable quartz cuvettes according to the combinations given in table 2 .

The contents of the cuvettes were mixed by inversion and temperature maintained at $25^{\circ} \mathrm{C}$. The wavelength, $\mathrm{A}_{295 \mathrm{~nm}}$ is monitored until constant, using a spectrophotometer (Shimadzu UV-1800). After adding the enzyme, the cuvette contents are again thoroughly mixed by inversion and the increase in absorbance recorded for approximately 5 mins [21].

Table 2:-

\begin{tabular}{|l|c|c|c|c|c|}
\hline \multirow{2}{*}{ Reagent } & \multicolumn{4}{c|}{ Test (ml) } & \multirow{2}{*}{ Blank (ml) } \\
\cline { 2 - 5 } & A & B & C & D & \\
\hline Reagent A (Buffer) & 1.90 & 1.90 & 1.90 & 1.90 & 1.90 \\
\hline Reagent B (Xanthine) & 1.00 & 1.00 & 1.00 & 1.00 & 1.00 \\
\hline Deionised Water & - & - & - & - & 0.10 \\
\hline Reagent C(EnzymeSolution) & 0.10 & 0.10 & 0.10 & 0.10 & - \\
\hline $\begin{array}{c}1 \% \text { Sample solutions of MSG, } \\
\text { Tomato and Mushroom } \\
\text { respectively }\end{array}$ & - & 0.10 & 0.10 & 0.10 & - \\
\cline { 2 - 5 } & - & Tomato & Mushroom & MSG & \\
\cline { 2 - 5 } & & 0.20 & 0.20 & 0.20 & - \\
Tomato & Mushroom & MSG & \\
\hline
\end{tabular}

\section{Calculation:-}

One IU of Xanthine oxidase activity can be expressed as the quantity of enzyme required to produce $1 \mu$ mole of uric acid per minute ${ }^{[21]}$. The amount of uric acid formed per minute can be determined from the change in absorbance per minute as follows:

$\mu$ mole of uric acid per minute/ $\mathrm{ml}$ of xanthine oxidase

$$
=\frac{\Delta \text { Absorbance } / \mathrm{min} \times \text { reactionvolume } \times 1000}{\text { molarabsorptivitycoefficient } \times \text { mlofenzyme }}(1)
$$




\section{Result and discussion:-}

Xanthine oxidase is a superoxide-generating enzyme that is present in a variety of living species ranging from microorganisms to humans ${ }^{[17]}$. Xanthine oxidase (XOD) is generally present in our body in the form of $\mathrm{NADH}^{+}$ dependent xanthine dehydrogenase (XD) which has no role in initiation of oxidative stress. Certain pathological conditions such as ischemia lead to conversion of xanthine dehydrogenase to xanthine oxidase ${ }^{[14,27,28] .}$ Basically, xanthine oxidase catalyses the conversion of xanthine/hypoxanthine to uric acid and generates superoxide radicals $\left(\mathrm{O}_{2}{ }^{-}\right)$during the process. Hydrogen peroxide formed from these superoxide radicals can be further converted to highly reactive hydroxyl radical $\left(\mathrm{HO}^{-}\right)$. The hydroxyl radical is responsible for initiating oxidative stress in the body ultimately leading to tissue damage ${ }^{[22]}$

Researchers have observed that on administrating MSG, at a dose level of 4 and $8 \mathrm{mg} / \mathrm{g}$ body weight of adult male mice there was some alterations in the activities of free radical scavenging and free radical initiating enzymes such as Superoxide dismutase (SOD), Catalase (CAT) and XOD present in the hepatic tissue. The activities of radical scavenging enzymes such as SOD and CAT were reduced and that of free radical initiating enzyme,XOD was increased ${ }^{[23]}$.

In this paper we tried to differentiate between natural and artificial sources of MSG based on the aforementioned studies of xanthine oxidase activity.

The xanthine oxidase activity in the presence of artificial and natural sources of glutamate at different concentrations was calculated using equation (1). The tabular representation of the xanthine oxidase activities is depicted in Tables 3, 4 and 5. As is clear from Table 3, the activity of xanthine oxidase increased with the addition of $0.1 \mathrm{ml}$ of $1 \%$ MSG solution and again dropped slightly when treated with $0.2 \mathrm{ml}$ of $1 \%$ MSG solution. In Table 4 , the enzyme activity is seen to increase when $0.1 \mathrm{ml}$ of $1 \%$ xanthine oxidase solution is added and increase further when $0.2 \mathrm{ml}$ of $1 \%$ tomato solution is added. The Table 5depicts the enzyme activity in presence of mushroom which follows a similar trend as MSG i.e., the activity increases in the presence of $0.1 \mathrm{ml}$ of $1 \%$ mushroom solution and decreases again when subjected to $0.2 \mathrm{ml}$ of $1 \%$ mushroom solution. Thus, the data obtained show both artificial and natural glutamate enhances the activity of xanthine oxidase. Also increase in concentration of glutamate (both natural and artificial) had no significant effect on the activity.

Table 3:-Enzyme activity of only Xanthine Oxidase (XOD), with $0.1 \mathrm{ml} 1 \%$ MSG solution and $0.2 \mathrm{ml}$ of $1 \%$ MSG solution.

\begin{tabular}{|c|c|}
\hline Test Combination & Enzyme Activity(Unit / ml enzyme)* \\
\hline XOD & 0.152 \\
\hline XOD + 0.1 ml MSG & 0.1654 \\
\hline XOD + 0.2 ml MSG & 0.1644 \\
\hline
\end{tabular}

Table 4:-Enzyme activity of only Xanthine Oxidase (XOD), with $0.1 \mathrm{ml} 1 \%$ Tomato solution and $0.2 \mathrm{ml}$ of $1 \%$ Tomato solution.

\begin{tabular}{|c|c|}
\hline Test Combination & Enzyme Activity(Unit / ml enzyme)* \\
\hline XOD & 0.152 \\
\hline XOD + 0.1 ml Tomato & 0.2256 \\
\hline XOD + 0.2 ml Tomato & 0.2436 \\
\hline
\end{tabular}

Table 5:-Enzyme activity of only Xanthine Oxidase (XOD), with $0.1 \mathrm{ml} 1 \%$ Mushroom solution and $0.2 \mathrm{ml}$ of $1 \%$ Mushroom solution.

\begin{tabular}{|c|c|}
\hline Test Combinations & Enzyme activity (Unit / ml enzyme)* \\
\hline XOD & $\mathbf{0 . 1 5 2}$ \\
\hline XOD + 0.1 ml Mushroom & $\mathbf{0 . 1 9 3}$ \\
\hline XOD $+0.2 \mathrm{ml}$ Mushroom & $\mathbf{0 . 1 8 3}$ \\
\hline
\end{tabular}

* The values for the enzyme activity given in the tables above are the average of 3 set of trials.

\section{Conclusion:-}

This study was conducted as per standard procedures and the results were validated by repeating each trial three times. The findings of this study revealed similar chemical behavior of both natural and artificial glutamate. Both the 
natural and artificial sources of glutamate generated similar UV-Vis spectral data for xanthine oxidase activity. The results obtained were in accordance with previous research that suggest human body is unable to distinguish between synthetic and natural glutamate ${ }^{[7,8]}$. Thus, further research needs to be done to find a method of distinction that is not influenced by the human metabolism.

\section{Acknowledgement:-}

This work is supported and funded by M. E.Meeran Innovation Centre, Eastern Condiments Pvt Ltd, Cochin, India.

\section{References:-}

1. Almeida, N. F., Mulchandani, K. (1993):AnalyticalChimicaActa. 282, 353.

2. Baskaran, S., Lakshmi, S. and Prasad, P. R. (1999):Effect of cigarette smoke on lipid peroxidation and antioxidant enzymes in albino rat. Ind. J. Exp. Biol. 37, 1196-1200.

3. Beljaarr, P. R., Vandijk,R., Bisschop, E., Spiegelenberg, W.M.(1996): Journal of AOAC International. 79,697.

4. Biodun, D. and Biodun. A., (1993): A spice or Poison? Is Monosodium Glutamate safe for consumption? National Concorde, 5.

5. Bray, R. C.(1962): Spectrophotometric studies on the reduction of Xanthine Oxidase. Biochemical Journal. $83,11$.

6. Choudhary, P., Malik, V. B. T., Puri, S. and Ahluwalia, P.(1996): Studies on the effect of monosodium glutamate on the microsomal lipid peroxidation, calcium, ascorbic acid and glutathione and its dependent enzymes in adult male mice. Toxicol. Lett, 89, 71-76.

7. Daniels, D., Joe, F., and Diachenko, G. (1995): Determination of free glutamic acid in a variety of foods by high performance liquid chromatography. Food additives and Contaminants. 12(1): 21-29.

8. Federation of American Societies for Experimental Biology (FASEB)(1995): Analysis of the Adverse Reactions to Monosodium Glutamate (MSG). Prepared by the Life Science Research Office, FASEB, for the Center of Food Safety and Applied Nutrition, U. S. Food and Drug Administration. Bethesda, Maryland: FASEB.

9. Fernstorm, J.D.(2000): Second International Conference on Glutamate: Conference Summary. J. Nutr., 130:1077S-1079S.

10. Filler, L.J. and Stegnik, L.D. (1994): Report of the proceedings of the glutamate workshop, August 1991. Crit. Rev. Food Sci. Nutr., 34 (2):159-174.

11. Fridovich, I. (1970): Quantitative Aspects of the production of Superoxide anion radical by milk Xanthine Oxidase. The Journal of Biological Chemistry. 245, 4053-4057.

12. Fuke, S. and Shimizu, T. (1993): Sensory and preference aspects of umami. Trends in Food Sci. \&Technol., 4:246-251.

13. Geha, R.S., Belser, A., Ren, c., Patterson R., Greenberger, P. A., Grammer, L.C., Ditto, A. M., Harria, K. E., Shaughnessy, M. Yarnold, P.R., Corren, J. and Saxon, A. (2000) : Review of alleged reaction to monosodium glutamate and outcome of a multicentre double-blind placebo controlled study. J.Nutr, 130, 1058S-1062S.

14. Granger, D.N., Rutili, G. and McCord, J. M. (2000): Superoxide radicals in feline intestinal ischemia. Gastroenterology. 8, 474, X.

15. Institute of Food TechnologistsExpert Panel on Food Safety and Nutrition.(1987.a): Monosodium Glutamate. Food technol.,41(5):143-145.

16. Intrnational Standard (ISO), 4134, 1978. Meat and Meat Products.Determination L-(+) - glutamic acid content, $1^{\text {st }} \mathrm{Ed}$.

17. Kale, R. K. (2003): Post irradiation free generation: Evidence from the conversion of xanthine dehydrogenase to xanthine oxidase. Ind. J. Exp. Biol. 41, 105-111.

18. Parks, D.A. and Granger, D. N. (1986): Xanthine Oxidase: Biochemistry, Distribution and Physiology. ActaPhysiologicaScandinavica Supplement. 548, 87-99.

19. Roussos, G. G.(1967): P Xanthine Oxidase from Bovine small intestine. Methods in enzymology. 12, 5-16.

20. Samuels, A. (1999): Toxicity/ Safety of MSG: A study in Suppression of Information. Accountability in Research, Vol. 6, No. 4, 259-310.

21. Shintani, H. (2013): Determination of Xanthine Oxidase. Pharmaceutica Analytical Acta. S7-004. 
22. Singh, K. and Ahluwalia, P.(2005): Alteration in some antioxidant enzymes in cardiac tissue upon Monosodium Glutamate (MSG) administration to adult male mice. Indian Journal of Clinical Biochemistry. 20(1), 43-46.

23. Singh, K. and Ahluwalia, P. (2002): Studies on the effect of Monosodium Glutamate (MSG) administration on the activity of xanthine oxidase, superoxide dismutase and catalase in hepatic tissue of adult male mice. Indian Journal of Clinical Biochemistry. 17(1), 29-33.

24. Stalikas, C.D. ,Karayannis, M.I., Tzouwara-Karayanni,S.,(1994): Talanta.41, 1561.

25. Tawfik, M. S. and Al-Badr, N. (2012): Adverse Effect of Monosodium Glutamate on Liver and Kidney functions in Adult Rats and Potential Protective Effect of Vitamin C and E. Food and Nutrition Sciences. 3,651-659.

26. Terada, L.S., Leff, J. A., Repine, (1990): J.E. Measurement of Xanthine oxidase in biological tissues. Methods in Enzymology.186, 651-656.

27. Wiezorek, J. S., Brown, D. N., Kupperman, D. E. and Brass, C. A. (1994): Rapid conversion to high xanthine oxidase activity in viable kupffer cells during hypoxia. J. Clin. Invest. 94, 24-28.

28. Xu, P., Huekstead, P., Harrison, R. and Hoidal, J. R. (1994): Molecular Cloning, tissue expression of human xanthine dehydrogenase. Biochem. Biophy. Res. Commun. 199, 998.

29. Yamaguchi, S. and Ninomaya, K. (2000): Umami and Food palatability. J.Nutr. 130:921S-926S. 